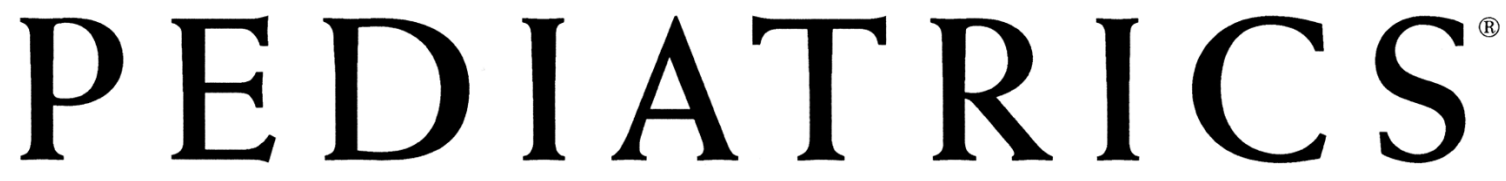

OFFICIAL JOURNAL OF THE AMERICAN ACADEMY OF PEDIATRICS

\title{
Mothers' Spanking of 3-Year-Old Children and Subsequent Risk of Children's Aggressive Behavior
}

Catherine A. Taylor, Jennifer A. Manganello, Shawna J. Lee and Janet C. Rice Pediatrics published online Apr 12, 2010;

DOI: $10.1542 /$ peds.2009-2678

The online version of this article, along with updated information and services, is located on the World Wide Web at:

http://www.pediatrics.org

PEDIATRICS is the official journal of the American Academy of Pediatrics. A monthly publication, it has been published continuously since 1948. PEDIATRICS is owned, published, and trademarked by the American Academy of Pediatrics, 141 Northwest Point Boulevard, Elk Grove Village, Illinois, 60007. Copyright ( 2010 by the American Academy of Pediatrics. All rights reserved. Print ISSN: 0031-4005. Online ISSN: 1098-4275.

\section{American Academy of Pediatrics}




\section{Mothers' Spanking of 3-Year-0ld Children and Subsequent Risk of Children's Aggressive Behavior}

AUTHORS: Catherine A. Taylor, PhD, MSW, MPH, ${ }^{\text {a Jennifer }}$ A. Manganello, PhD, MPH, ${ }^{b}$ Shawna J. Lee, PhD, MSW, MPP, ${ }^{c}$ and Janet C. Rice, $\mathrm{PhD}^{\mathrm{d}}$

Departments of ${ }^{a}$ Community Health Sciences and diostatistics, School of Public Health and Tropical Medicine, Tulane University, New Orleans, Louisiana: ${ }^{b}$ Department of Health Policy, Management, and Behavior, School of Public Health, University at Albany, State University of New York, Rensselaer, New York; and ${ }^{c}$ Merrill-Palmer Skillman Institute for Child and Family Development, School of Social Work, Wayne State University, Detroit, Michigan

\section{KEY WORDS}

corporal punishment, child discipline, spank, childhood aggression, child aggressive behavior

\section{ABBREVIATIONS}

$\mathrm{CP}$ - corporal punishment

FFCWS-Fragile Families and Child Well-being Study

www.pediatrics.org/cgi/doi/10.1542/peds.2009-2678

doi:10.1542/peds.2009-2678

Accepted for publication Jan 7, 2010

Address correspondence to Catherine A. Taylor, PhD, MSW, MPH, Tulane University School of Public Health and Tropical Medicine, Department of Community Health Sciences, 1440 Canal St, Suite 2301 TW19, New Orleans, LA 70112. E-mail: ctaylor5@tulane.edu PEDIATRICS (ISSN Numbers: Print, 0031-4005; Online, 1098-4275). Copyright (@) 2010 by the American Academy of Pediatrics FINANCIAL DISCLOSURE: The authors have indicated they have no financial relationships relevant to this article to disclose. Funded by the National Institutes of Health (NIH)
WHAT'S KNOWN ON THIS SUBJECT: Dozens of studies have shown a significant statistical link between the use of CP with children and child aggression, including many studies that controlled for the child's initial level of aggression.

WHAT THIS STUDY ADDS: With controlling for the child's initial level of aggression, demographic features, and 8 potential parenting risk confounders, which to our knowledge have not previously been controlled simultaneously, more-frequent use of CP increased the risk for higher levels of child aggression.

OBJECTIVE: The goal was to examine the association between the use of corporal punishment (CP) against 3-year-old children and subsequent aggressive behavior among those children.

METHODS: Respondents $(N=2461)$ participated in the Fragile Families and Child Well-being Study (1998-2005), a population-based, birth cohort study of children born in 20 large US cities. Maternal reports of $\mathrm{CP}$, children's aggressive behaviors at 3 and 5 years of age, and a host of key demographic features and potential confounding factors, including maternal child physical maltreatment, psychological maltreatment, and neglect, intimate partner aggression victimization, stress, depression, substance use, and consideration of abortion, were assessed.

RESULTS: Frequent use of CP (ie, mother's use of spanking more than twice in the previous month) when the child was 3 years of age was associated with increased risk for higher levels of child aggression when the child was 5 years of age (adjusted odds ratio: 1.49 [95\% confidence interval: 1.2-1.8]; $P<.0001$ ), even with controlling for the child's level of aggression at age 3 and the aforementioned potential confounding factors and key demographic features.

CONCLUSIONS: Despite American Academy of Pediatrics recommendations to the contrary, most parents in the United States approve of and have used $\mathrm{CP}$ as a form of child discipline. The current findings suggest that even minor forms of $\mathrm{CP}$, such as spanking, increase risk for increased child aggressive behavior. Importantly, these findings cannot be attributed to possible confounding effects of a host of other maternal parenting risk factors. Pediatrics 2010;125:e1057-e1065 
When parents discipline their children, they generally do so to teach their children a lesson, to instill values, and/or to improve their children's current and future behavior. Corporal punishment $(\mathrm{CP})$ is one disciplinary strategy that remains highly prevalent in the United States despite controversy surrounding its use. ${ }^{1}$ Estimates of US parents who have used CP vary from $35 \%$ to $90 \%$, depending on key modifiers such as the age and gender of the child and the type of punishment specified (eg, spanking or slapping).$^{2-5}$ In a 2005 US poll, $72 \%$ of adults reported that it was "OK to spank a child," with approval ratings being highest in the South and lowest in the Northeast. ${ }^{6}$

The normativeness of $\mathrm{CP}$ in the United States stands in contrast to the recommendations of the American Academy of Pediatrics, which are consistent with those of other professional organizations, ${ }^{7-9}$ that "parents be encouraged and assisted in the development of methods other than spanking for managing undesired behavior."'(p723)10 Such concerns are rooted in the increasing body of empirical evidence suggesting that the risks of using $\mathrm{CP}$ against children are likely to outweigh the potential benefits. A 2002 metaanalysis showed linkages between CP of children and risk for poor outcomes in childhood, including aggressive and/or antisocial behavior, mental health problems, and physical maltreatment. ${ }^{11}$

Whether CP causes aggression is of particular relevance for public health interests in disrupting the cycle of violence. The meta-analysis performed by Gershoff ${ }^{11}$ found the link between CP and aggression to be positive ( $d=$ 0.36 ); however, most of those studies were not longitudinal. ${ }^{12}$ To assert more strongly that CP is a causal determinant of aggression, it is necessary to demonstrate a statistically significant and temporally specific link between $\mathrm{CP}$ and aggression and also to control for the child's initial level of aggression and key potential confounders. ${ }^{11,12}$ 0ther researchers have aimed to meet most of these conditions. ${ }^{13-22}$ However, the current study accounts for all 4 conditions, has a larger sample size and therefore more statistical power than all except 2 of the aforementioned studies, 21,22 and controls for key potential maternal parenting risk confounders that previously have not been examined simultaneously. The current study was designed to answer the following question: is a mother's use of $\mathrm{CP}$ on a 3 year-old child linked to risk for that child being more aggressive at 5 years of age, even after controlling for the child's initial level of aggression at age 3 and other important maternal parenting risk factors and demographic features?

\section{METHODS}

\section{Participants}

The sample was obtained from the Fragile Families and Child Well-being Study (FFCWS), a population-based, cohort study of families from 20 large US cities. The original sample $(N=4898)$ was obtained from 1998 to 2000 by sampling births within hospitals in cities with populations of $>200000$ in 1994; a detailed description of the FFCWS design was published previously. ${ }^{23}$ Four waves of data are available, that is, baseline (time of the index child's birth) and index child ages of 1 , 3 , and 5 years. Two interviews were conducted when the child was 3 and 5 years of age, a core interview and an interview conducted with a subsample of mothers for the add-on In-Home Longitudinal Study of Preschool-Aged Children. Questions about child aggression and maltreatment were included in the latter interview.

Mothers who met $\geq 1$ of the following criteria were excluded from the study sample: did not participate in the 3-year in-home interview $(n=1610)$ or, in the 5-year in-home interview $(n=799)$, answered $<50 \%$ of the child aggression scale items, so that a valid score could not be calculated (missing item values were imputed when $\leq 50 \%$ of the scale items were missing) ( $n=$ $21)$, or did not report whether they had spanked the index child at age 3 ( $n=$ 7). Study participants $(n=2461)$ were more likely than nonparticipants ( $n=$ 2437) to have some college education, to be black, to have been born in the United States, and to be Christian (nonCatholic) or nonreligious ( $\chi^{2}$ tests, $P<$ .05). Participants and nonparticipants did not differ according to child's gender, mother's age, household income, or marital status at child's birth.

The institutional review board of the Tulane University Health Sciences Center reviewed this secondary data analysis study and considered it exempt. Participant recruitment procedures were approved by the institutional review boards at Columbia University and Princeton University, the academic homes to the FFCWS. Additional details pertaining to the original study were published elsewhere. ${ }^{23}$

\section{Measures}

\section{Data Collection}

All data were provided through selfreport from the mother. All childrelated questions were asked with respect to the identified index child.

\section{Predictor Variable: Mother's Use of CP}

This variable reflects how frequently the mother spanked her 3-year-old child (a peak age for spanking use ${ }^{2,24}$ ) for "misbehaving or acting up" in the month before the interview. Responses were coded as never (score of 0 ), once or twice (score of 1), or $>2$ times (score of 2).

Dependent Variable: Index Child's Aggression at Age 5

This was assessed by using 12 items from the Child Behavior Checklist ver- 
sion for age $5,{ }^{25}$ which asked whether the child argues a lot; is cruel, bullies, and shows meanness to others; destroys his or her own things; destroys things belonging to family members or others; is disobedient at home; is disobedient at school or in child care; gets in many fights; physically attacks people; screams a lot; teases a lot; threatens people; or is unusually loud $(\alpha=$.82). Response options were not true (score of 0 ), somewhat or sometimes true (score of 1), or very true or often true (score of 2). An average score for the 12 items was obtained (mean: 0.40; median: 0.33; SD: 0.33). Because the variable was highly skewed, it was dichotomized at the median and analyzed as lower aggression (scores of $0-0.32$ ) versus higher aggression (scores of $0.33-1.83$ ).

\section{Index Child's Aggression at Age 3}

This was assessed by using 19 items from the Child Behavior Checklist version for age $3,{ }^{25}$ which asked whether the child is defiant; has demands that must be met immediately; is disobedient; does not seem to feel guilty after misbehaving; is easily frustrated; gets in many fights; hits others; has angry moods; shows behavior that punishment does not change; screams a lot; is selfish or will not share; is stubborn, sullen, or irritable; has temper tantrums or hot temper; is uncooperative; wants a lot of attention; cannot stand waiting and wants everything now; destroys things belonging to family members or other children; hurts animals or people without meaning to; or physically attacks people $(\alpha=.88)$. Response options were not true (score of $0)$, somewhat or sometimes true (score of 1), or very true or often true (score of 2). An average score for the 19 items was obtained (mean: 0.62; median: 0.58; SD: 0.36). Because the variable was highly skewed, it was dichotomized at the median value and analyzed as lower aggression (scores of $0-0.57)$ versus higher aggression (scores of $0.58-1.95$ ).

\section{Maternal Parenting Risks}

Mother's use of CP is associated with use of other harsh parenting (physical and psychological maltreatment; the term "maltreatment" is used throughout for these variables, rather than the more-commonly used term "aggression," so that these variables are not confused with the outcome variable of child aggression), child neglect, intimate partner aggression and violence, and maternal parenting stress, depression, and consideration of abortion ${ }^{5}$; use of alcohol and/or drugs also is linked with use of CP. ${ }^{26}$ Literature findings showed links between most of these variables (especially harsh parenting, exposure to intimate partner aggression, parental depression, and parental stress) and childhood aggression. ${ }^{27-32}$ Therefore, these variables, which were assessed when the child was age 3 , for consistency with the main predictor variable, might confound the association between $\mathrm{CP}$ and child aggression.

\section{Child Maltreatment and Intimate Partner Aggression and Violence}

Three child maltreatment proxies were assessed with the Parent-Child Conflict Tactics Scale, ${ }^{33}$ that is, physical maltreatment (4 items), psychological maltreatment (5 items), and neglect (5 items). (The physical maltreatment scale usually contains a fifth item regarding spanking; however, this item was removed so that it would not overlap with our main predictor variable.) Intimate partner aggression or violence experienced by the mother since the index child's birth, either from the father or from a current partner, was assessed by using 7 items; 3 items from the Conflict Tactics Scale ${ }^{34}$ were adapted to assess physical aggression and 4 from the Spouse Observation Checklist $^{35}$ and the report by
Lloyd ${ }^{36}$ were adapted to assess psychological aggression. Because child physical and psychological maltreatment results were highly skewed, they were dichotomized at their median values (Table 1) for analysis. Child neglect and intimate partner aggression or violence also were dichotomized (any versus none).

\section{Other Maternal Risks}

Maternal parenting stress, major depression, use of alcohol and/or drugs, and unwantedness of the index child pregnancy were assessed. Stress was measured by using 11 items from the Parenting Stress Index ${ }^{37}(\alpha=.86)$. Depression was measured on the basis of criteria from the Diagnostic and Statistical Manual of Mental Disorders, Fourth Edition ${ }^{38}$ for major depression, by using section $A$ of the Composite International Diagnostic InterviewShort Form ${ }^{39}$; detailed scoring methods were described previously. ${ }^{40}$ Assessment of alcohol and other drug use also was derived from the Composite International Diagnostic InterviewShort Form ${ }^{39}$ and was coded positively if the mother had had $\geq 4$ drinks on one day, or had used any of nine different substances at least once, in the past 12 months. "Unwantedness" of the index child pregnancy was approximated on the basis of the mother's response to the following baseline question: "When you found out you were pregnant, did you think about having an abortion?" Parenting stress was analyzed as a continuous variable. All of the other maternal risk variables were dichotomized (yes versus no).

\section{Family Demographic Features}

Family demographic features were selected on the basis of their availability in the FFCWS data set and previous empirical evidence suggesting their association with parenting risk and/or use of $C P$. 
TABLE 1 Descriptive and Bivariate Statistical Analyses of Maternal Characteristics According to Mother's Use of CP in Month Before Interview When Child Was 3 Years of Age

\begin{tabular}{|c|c|c|c|c|c|}
\hline & $\begin{array}{l}\text { Total Sample } \\
(N=2461)\end{array}$ & $\begin{array}{l}\text { Did Not Spank } \\
\quad(n=1123)\end{array}$ & $\begin{array}{l}\text { Spanked } 1 \text { or } 2 \\
\text { Times }(n=686)\end{array}$ & $\begin{array}{c}\text { Spanked } \geq 3 \\
\text { Times }(n=652)\end{array}$ & $P$ \\
\hline \multicolumn{6}{|l|}{ Maternal parenting risks } \\
\hline $\begin{array}{l}\text { Psychological maltreatment of child, no. of } \\
\text { incidents in previous year, median } \\
\text { (range: } 0-115 \text { incidents) }\end{array}$ & 25 & 16 & 25 & 33 & $<.001$ \\
\hline $\begin{array}{l}\text { Physical maltreatment of child (spanking } \\
\text { not included), no. of incidents in } \\
\text { previous year, median (range: } 0-108 \\
\text { incidents) }\end{array}$ & 12 & 4 & 16 & 26 & $<.001$ \\
\hline Any neglect of child in previous year, \% & 11.3 & 8.5 & 13.3 & 14.3 & $<.001$ \\
\hline $\begin{array}{l}\text { Victim of intimate partner aggression } \\
\text { and/or violence since birth of index } \\
\text { child, \% }\end{array}$ & 53.2 & 47.4 & 57.9 & 58.4 & $<.001$ \\
\hline $\begin{array}{l}\text { Parenting Stress Index score, median } \\
\quad \text { (range: 0-44) }\end{array}$ & 12 & 11 & 13 & 13 & $<.001$ \\
\hline Major depression, \% & 21.3 & 18.2 & 21.4 & 26.5 & $<.001$ \\
\hline Use of drugs and/or alcohol, \% & 16.1 & 13.0 & 16.6 & 20.9 & $<.001$ \\
\hline Considered aborting this child, \% & 27.7 & 24.8 & 29.3 & 30.8 & $<.05$ \\
\hline \multicolumn{6}{|l|}{ Mother and family demographic features } \\
\hline Male child, \% & 51.9 & 48.9 & 53.4 & 55.5 & $<.05$ \\
\hline Mother's age, median, y (range: 16-50 y) & 27 & 28 & 27 & 26 & $<.001$ \\
\hline Mother's education, $\%$ & & & & & $<.01$ \\
\hline Less than high school & 32.7 & 34.9 & 34.1 & 27.5 & $<.01$ \\
\hline High school & 30.6 & 29.1 & 29.2 & 34.8 & $<.05$ \\
\hline Some college & 25.6 & 23.9 & 26.2 & 27.8 & \\
\hline College graduate & 11.0 & 12.1 & 10.2 & 9.8 & \\
\hline Mother's race/ethnicity, \% & & & & & $<.001$ \\
\hline Black & 50.7 & 45.3 & 53.6 & 56.8 & $<.001$ \\
\hline Hispanic & 24.2 & 29.2 & 23.3 & 16.4 & $<.001$ \\
\hline White & 21.9 & 21.9 & 19.7 & 24.1 & \\
\hline Other & 3.1 & 3.2 & 3.2 & 2.6 & \\
\hline Mother foreign-born, \% & 12.6 & 17.5 & 10.5 & 6.1 & $<.001$ \\
\hline Mother's religion, \% & & & & & $<.001$ \\
\hline Catholic & 26.4 & 32.3 & 26.8 & 15.8 & $<.001$ \\
\hline Protestant & 39.9 & 36.0 & 40.2 & 46.3 & $<.001$ \\
\hline Other Christian & 12.7 & 11.0 & 12.4 & 16.1 & $<.01$ \\
\hline No religious preference & 17.0 & 16.6 & 16.8 & 17.9 & \\
\hline Other & 3.1 & 3.5 & 2.9 & 2.8 & \\
\hline Mother-father relationship status, \% & & & & & NS \\
\hline Married & 32.1 & 33.6 & 31.5 & 30.4 & \\
\hline Cohabiting & 27.7 & 28.0 & 26.7 & 28.2 & \\
\hline Visiting & 29.6 & 27.8 & 30.9 & 31.3 & \\
\hline No relationship & 10.6 & 10.6 & 10.9 & 10.1 & \\
\hline $\begin{array}{l}\text { Mother's annual household income, } \\
\text { median, In } \$ \text { (range: 0-13.8; actual } \\
\text { median: } \$ 23721 \text { ) }\end{array}$ & 10 & 10 & 10 & 10 & NS \\
\hline
\end{tabular}

NS indicates not statistically significant. Kruskal-Wallis tests were used for continuous variables, because equal-variance assumptions generally were not met; $\chi^{2}$ tests were used for binary and categorical variables. Missing data for each variable equaled $<1 \%$.

\section{Statistical Analyses}

Descriptive and bivariate statistical analyses were conducted to examine associations between all assessed maternal parenting risk factors/demographic features and mother's use of $\mathrm{CP}$ (Table 1) and child aggression at age 5 (Table 2). The Kruskal-Wallis test was used for continuous variables because the assumption of equal variances generally was not met; $\chi^{2}$ tests were used for binary and categorical variables.

Four multivariate logistic regression models were used to examine prediction of child aggression at age 5 (Table
3). Each model controlled for parents' marital status at the time of the index child's birth and interview city, because these variables were part of the sampling design. Model 1 tested use of $\mathrm{CP}$ when the child was 3 years of age as the sole predictor. Model 2 added the child's level of aggression at age 3 . 
TABLE 2 Descriptive and Bivariate Statistical Analyses of Maternal Characteristics According to Child Aggressive Behavior When Child Was 5 Years of Age

\begin{tabular}{|c|c|c|c|c|}
\hline & $\begin{array}{l}\text { Total Sample } \\
(N=2461)\end{array}$ & $\begin{array}{l}\text { Lower } \\
\text { Aggression } \\
(n=1137)\end{array}$ & $\begin{array}{c}\text { Higher } \\
\text { Aggression } \\
(n=1324)\end{array}$ & $P$ \\
\hline \multicolumn{5}{|l|}{ Maternal parenting risks } \\
\hline $\begin{array}{l}\text { Psychological maltreatment of child, no. of incidents } \\
\text { in previous year, median (range: } 0-115 \\
\text { incidents) }\end{array}$ & 25 & 18 & 27 & $<.001$ \\
\hline $\begin{array}{l}\text { Physical maltreatment of child (spanking not } \\
\text { included), no. of incidents in previous year, } \\
\text { median (range: } 0-108 \text { incidents) }\end{array}$ & 12 & 9 & 16 & $<.001$ \\
\hline Any neglect of child in previous year, $\%$ & 11.3 & 8.1 & 14.1 & $<.001$ \\
\hline $\begin{array}{l}\text { Victim of intimate partner aggression and/or } \\
\text { violence since birth of index child, } \%\end{array}$ & 53.2 & 47.9 & 57.8 & $<.001$ \\
\hline Parenting Stress Index score, median (range: $0-44$ ) & 12 & 11 & 13 & $<.001$ \\
\hline Major depression, \% & 21.3 & 17.5 & 24.6 & $<.001$ \\
\hline Use of drugs and/or alcohol, \% & 16.1 & 13.9 & 18.0 & $<.01$ \\
\hline Considered aborting this child, \% & 27.7 & 25.0 & 30.0 & $<.01$ \\
\hline \multicolumn{5}{|l|}{ Mother and family demographic features } \\
\hline Male child, $\%$ & 51.9 & 47.5 & 55.7 & $<.001$ \\
\hline Mother's age, median, y (range: $16-50$ y) & 28 & 28 & 26 & $<.001$ \\
\hline Mother's education, $\%$ & & & & $<.001$ \\
\hline Less than high school & 32.7 & 29.4 & 35.6 & $<.01$ \\
\hline High school & 30.6 & 28.5 & 32.5 & $<.05$ \\
\hline Some college & 25.6 & 28.0 & 23.5 & $<.05$ \\
\hline College graduate & 11.0 & 14.1 & 8.3 & $<.001$ \\
\hline Mother's race/ethnicity, \% & & & & NS \\
\hline Black & 50.7 & 49.3 & 51.9 & \\
\hline Hispanic & 24.2 & 24.4 & 24.0 & \\
\hline White & 21.9 & 23.3 & 20.6 & \\
\hline Other & 3.1 & 2.9 & 3.2 & \\
\hline Mother foreign-born, \% & 12.6 & 13.5 & 11.7 & NS \\
\hline Mother's religion, \% & & & & $<.05$ \\
\hline Catholic & 26.4 & 27.7 & 25.3 & \\
\hline Protestant & 39.9 & 41.3 & 38.7 & \\
\hline Other Christian & 12.7 & 12.7 & 12.8 & \\
\hline No religious preference & 17.0 & 14.5 & 19.1 & $<.01$ \\
\hline Other & 3.1 & 3.1 & 3.2 & \\
\hline Mother-father relationship status, $\%$ & & & & $<.001$ \\
\hline Married & 32.1 & 36.6 & 28.3 & $<.001$ \\
\hline Cohabiting & 27.7 & 27.1 & 28.2 & \\
\hline Visiting & 29.6 & 25.9 & 32.8 & $<.001$ \\
\hline No relationship & 10.6 & 10.4 & 10.7 & \\
\hline $\begin{array}{l}\text { Mother's annual household income, In } \$ \text { (range: } \\
\quad 0-13.8 \text {; actual median: } \$ 23721 \text { ) }\end{array}$ & 10.1 & 10.1 & 10.0 & $<.001$ \\
\hline
\end{tabular}

NS indicates not statistically significant. Kruskal-Wallis tests were used for continuous variables, because equal-variance assumptions generally were not met; $\chi^{2}$ tests were used for binary and categorical variables. Missing data for each variable equaled $<1 \%$.

Model 3 added the assessed maternal parenting risk factors. Model 4 added all of the assessed demographic features.

\section{RESULTS}

Almost one-half (45.6\%) of the mothers reported no use of spanking in the previous month, $27.9 \%$ reported spanking 1 or 2 times, and $26.5 \%$ reported spanking $>2$ times. All of the examined risk factors and demographic features, except for parental relationship status and income, were significantly associated with $\mathrm{CP}$ in bivariate analyses (Table 1). More-frequent use of CP was significantly associated with increased maternal parenting risks. Respondents who had a male index child or a high school education or who were younger, black, or Christian (nonCatholic) were at higher-than-average risk for using $\mathrm{CP}$, whereas those who were Hispanic, foreign-born, or Catholic were at lower-than-average risk.

As with CP, higher levels of each of the assessed maternal parenting risks were associated with risk for higher levels of child aggression (Table 2). These findings confirmed that these parenting risk factors might indeed confound the link between $\mathrm{CP}$ and child aggression and therefore should be controlled for in the final analysis. In addition, children who were male or whose mothers were younger, had lower education levels or household income, had no religious preference, or had just a "visiting" relationship with the father were at risk for higher levels of aggression. Race/ethnicity and nativity were not associated with child aggression.

Table 3 presents results from 4 logistic regression models predicting higher levels of child aggression at age 5 . Across all 4 models, mothers' morefrequent use of $\mathrm{CP}$ ( $>2$ times in the previous month) when the child was age 3 was a statistically significant predictor of higher levels of aggression when the child was age 5 . At the bivariate level (model 1), morefrequent use of CP more than doubled the odds of higher aggression levels, and less-frequent use of CP (1 or 2 times in the previous month) increased the odds by almost $40 \%$. When the child's level of aggression at age 3 was included (model 2), the impact of $\mathrm{CP}$ use on subsequent aggression was decreased almost in half; this was because, as expected, having a higher level of aggression at age 3 was a strong predictor of having a higher level of aggression at age 5 . When the assessed maternal parenting risks were included (model 3), the impact of more-frequent CP use was decreased by another $27 \%$ and less-frequent CP 
TABLE 3 ORs of CP and Other Family Characteristics Predicting Higher Levels of Child Aggression at Age 5

\begin{tabular}{|c|c|c|c|c|c|c|c|c|}
\hline & \multicolumn{2}{|c|}{ Model $1(N=2461)$} & \multicolumn{2}{|c|}{ Model $2(N=2461)$} & \multicolumn{2}{|c|}{ Model $3(N=2432)$} & \multicolumn{2}{|c|}{ Model $4(N=2432)$} \\
\hline & OR $(95 \% \mathrm{Cl})$ & $P$ & OR $(95 \% \mathrm{Cl})$ & $P$ & OR $(95 \% \mathrm{Cl})$ & $P$ & OR $(95 \% \mathrm{Cl})$ & $P$ \\
\hline \multicolumn{9}{|l|}{ Mother's use of $\mathrm{CP}$} \\
\hline Mother spanked $>2$ times & $2.03(1.82-2.26)$ & $<.0001$ & $1.59(1.42-1.79)$ & $<.0001$ & $1.43(1.22-1.69)$ & $<.0001$ & $1.49(1.24-1.78)$ & $<.0001$ \\
\hline Mother spanked 1 or 2 times & $1.37(1.17-1.61)$ & $<.0001$ & $1.21(1.02-1.45)$ & .032 & $1.15(0.93-1.40)$ & NS & $1.17(0.94-1.44)$ & NS \\
\hline Higher level of child aggression at age 3 & & & $3.79(3.43-4.19)$ & $<.0001$ & $3.34(3.05-3.66)$ & $<.0001$ & $3.35(3.06-3.67)$ & $<.0001$ \\
\hline \multicolumn{9}{|l|}{ Maternal parenting risks } \\
\hline Psychological maltreatment of child & & & & & $0.98(0.81-1.18)$ & NS & $0.97(0.80-1.19)$ & NS \\
\hline $\begin{array}{l}\text { Physical maltreatment of child (spanking not } \\
\text { included) }\end{array}$ & & & & & $1.11(0.95-1.28)$ & NS & $1.10(0.93-1.29)$ & NS \\
\hline Neglect of child & & & & & $1.14(0.84-1.55)$ & NS & $1.13(0.83-1.53)$ & NS \\
\hline $\begin{array}{l}\text { Victim of intimate partner aggression and/or } \\
\text { violence }\end{array}$ & & & & & $1.14(0.94-1.38)$ & NS & $1.15(0.94-1.39)$ & NS \\
\hline Parenting stress & & & & & $1.02(1.01-1.04)$ & .001 & $1.02(1.01-1.04)$ & .006 \\
\hline Major depression & & & & & $1.07(0.91-1.26)$ & NS & $1.07(0.92-1.25)$ & NS \\
\hline Use of drugs and/or alcohol & & & & & $1.14(0.87-1.50)$ & NS & $1.15(0.88-1.51)$ & NS \\
\hline Considered aborting this child & & & & & $1.04(0.79-1.37)$ & NS & $1.04(0.77-1.40)$ & NS \\
\hline \multicolumn{9}{|l|}{ Demographic features } \\
\hline Male child & & & & & & & $1.31(1.09-1.58)$ & .004 \\
\hline Mother's age & & & & & & & $1.00(0.97-1.03)$ & NS \\
\hline \multicolumn{9}{|l|}{ Mother's education } \\
\hline Less than high school (reference) & & & & & & & 1.00 & \\
\hline High school & & & & & & & $0.97(0.80-1.19)$ & NS \\
\hline Some college & & & & & & & $0.78(0.65-0.94)$ & .009 \\
\hline College graduate & & & & & & & $0.66(0.44-0.99)$ & .043 \\
\hline \multicolumn{9}{|l|}{ Mother's race/ethnicity } \\
\hline Black (reference) & & & & & & & 1.00 & \\
\hline Hispanic & & & & & & & $0.99(0.80-1.22)$ & NS \\
\hline White & & & & & & & $1.07(0.85-1.34)$ & NS \\
\hline Other & & & & & & & $1.13(0.72-1.80)$ & NS \\
\hline Mother foreign-born & & & & & & & $1.04(0.77-1.41)$ & NS \\
\hline \multicolumn{9}{|l|}{ Mother's religion } \\
\hline Protestant (reference) & & & & & & & 1.00 & \\
\hline Catholic & & & & & & & $1.10(0.75-1.60)$ & NS \\
\hline Other Christian & & & & & & & $0.99(0.64-1.55)$ & NS \\
\hline No religious preference & & & & & & & $1.24(1.02-1.50)$ & .030 \\
\hline Other & & & & & & & $1.32(0.77-2.26)$ & NS \\
\hline \multicolumn{9}{|l|}{ Mother-father relationship status } \\
\hline Married (reference) & & & & & & & 1.00 & \\
\hline Cohabiting & & & & & & & $0.99(0.70-1.39)$ & NS \\
\hline Visiting & & & & & & & $1.18(0.89-1.56)$ & NS \\
\hline No relationship & & & & & & & $1.00(0.65-1.54)$ & NS \\
\hline Mother's annual household income & & & & & & & $0.96(0.90-1.04)$ & NS \\
\hline
\end{tabular}

$\mathrm{OR}$ indicates odds ratio; $\mathrm{Cl}$, confidence interval. Missing data for each variable equaled $\leq 1.2 \%$. All models were adjusted for 2 key variables used in the sampling design, that is, parents marital status at time of index child's birth (married or unmarried) and city. In model 4, a Bonferroni correction for multiple tests suggested that only findings with $P<.002$ should be considered.

use was no longer statistically significant. The final model (model 4), which also included all assessed demographic features, suggests that the odds of the child having a higher level of aggression at age 5 were increased by $\sim 49 \%$ with more-frequent use of $\mathrm{CP}$ at age 3 .

\section{DISCUSSION}

Our study accounted for 8 maternal parenting risks for child aggression, including other forms of harsh parenting besides $\mathrm{CP}$, child neglect, intimate partner aggression or violence, and maternal parenting stress, depression, use of substances, and consideration of abortion. As anticipated, all of these factors were found to be associated both with $\mathrm{CP}$ use and with child aggression and therefore had the potential to be important confounders of this association. Although previous studies on this topic accounted for parenting risks such as maternal psychopathological conditions, ${ }^{22}$ parental marital adjustment or conflict, 14,15 and/or relevant demographic features, no other studies, to our knowledge, accounted simultaneously for all of the confounders addressed in this study while also addressing the other key conditions (statistical significance, temporality, and initial lev- 
els of child aggression) that must be met to assert more strongly that use of CP leads to higher levels of aggression in children.

We found that, even when all of those maternal parenting risks were controlled for, mothers' more-frequent use of $\mathrm{CP}$ with their 3-year-old children increased the odds of those children being more aggressive at age 5 . This finding is consistent with dozens of other studies that showed a significant statistical link between the use of $\mathrm{CP}$ and child aggression, including studies $^{17,19,41-51}$ summarized by Gershoff ${ }^{11}$ and other studies $22,52-55$ conducted since the time of that meta-analysis; it also is consistent with studies that similarly controlled for children's initial level of aggression. ${ }^{14-22}$ In our final model, CP was the only parenting risk factor examined that remained statistically linked (after Bonferroni correction) with subsequent child aggression. This finding seems to support a social learning approach to understanding the cycle of violence, ${ }^{56}$ whereby the child learns to be aggressive by being treated directly with aggression.

One may wonder, then, why child physical maltreatment by the mother was not related to child aggression. The physical maltreatment subscale of the Parent-Child Conflict Tactics Scale contained 5 items (shook; hit on the bottom with something like a belt, hairbrush, a stick, or some other hard object; slapped on the hand, arm, or leg; pinched; and spanked on the bottom with a bare hand). When the latter item was removed, however, there was a substantial decrease in the reliability coefficient for this subscale (from $\alpha=$ .63 to $\alpha=.48$ ). Furthermore, 2 of the remaining 4 items were reported very rarely (shook, 5\%; pinched, $8 \%$ ); spanking was much more common. Therefore, the lack of association be- tween child physical maltreatment by the mother and subsequent child aggression may be an issue of statistical power rather than theoretical inconsistency.

There are several limitations to our study. First, this study focused only on mothers' use of CP and did not account for fathers' or other caregivers' use of CP. Furthermore, all variables in this study were based on mothers' self-reports; there were no observational data, and reports might be subject to biases related to recall and/or social desirability. Also, there is always concern in observational studies that unmeasured confounders may explain the associations found; however, when this concern was addressed to some extent in a previous study by using hierarchical linear modeling, the link between $\mathrm{CP}$ and child aggression remained. ${ }^{21}$

Given the problem of potential unmeasured confounders, it is not possible to assert causality between $\mathrm{CP}$ and child aggression in observational studies such as this. As with other studies of risk behaviors (eg, smoking), it would be unethical to assign parents randomly to use $\mathrm{CP}$ or not to use $\mathrm{CP}$, given the existing evidence linking $\mathrm{CP}$ with associated harm in children. Therefore, we must rely largely on evidence from observational studies, such as the current one, that aim to account for as many other possible explanations of the association between CP and subsequent child aggression as possible.

\section{CONCLUSIONS}

This study adds to the growing body of literature suggesting that parental use of CP may lead to increased child aggression. This evidence base suggests that primary prevention of violence can start with efforts to prevent the use of CP against children. Pediatricians and others concerned with chil- dren's well-being know that CP is not a necessary form of child discipline and that other, more or equally effective, nonphysical forms of discipline exist. Reductions in parents' use of CP (demonstrated in randomized, clinical trials of parenting interventions designed to treat conduct disorder in children) have been shown to reduce children's subsequent aggression ${ }^{57}$; additional studies of this nature could aid in addressing the issue of CP as a causal agent in subsequent aggression. However, efforts to teach nonphysical discipline strategies to parents in general pediatric office visits have met with mixed success ${ }^{58,59}$ Research to further such efforts is needed, given that parents cite pediatricians as the professionals from whom they are most likely to seek advice regarding child discipline. ${ }^{60}$ In addition, broader population-based efforts, such as social marketing campaigns, are needed to shift normative beliefs and expected outcomes regarding $\mathrm{CP}^{60}$ and to strengthen the message of the American Academy of Pediatrics that other child discipline strategies that are effective and less risky should be used instead of CP.

\section{ACKNOWLEDGMENTS}

This research was supported by the Centers for Disease Control and Prevention (grant R49 CE000915-02) and the National Institute of Mental Health and the National Institute of Child Health and Human Development (grant R01 HD41141-02).

We thank Mili Duggal and Ransome Eke for their assistance with literature review and table construction, as well as Elizabeth Gershoff for sharing reviews of key literature. We also thank the 2461 study participants who gave their valuable time and information to this study, along with the anonymous reviewers for their helpful comments and critiques of this article. 


\section{REFERENCES}

1. Durrant JE. Physical punishment, culture, and rights: current issues for professionals. J Dev Behav Pediatr. 2008;29(1):55-66

2. Straus MA, Stewart JH. Corporal punishment by American parents: national data on prevalence, chronicity, severity, and duration, in relation to child and family characteristics. Clin Child Family Psychol Rev. 1999;2 (2):55-70

3. Daro D. Public Opinion and Behaviors Regarding Child Abuse Prevention: 1999 Survey. Chicago, IL: Prevent Child Abuse America; 1999

4. Day RD, Peterson GW, McCracken C. Predicting spanking of younger and older children by mothers and fathers. J Marriage Fam. 1998;60(1):79-94

5. Taylor CA, Guterman NB, Lee SJ, Rathouz PJ. Intimate partner violence, maternal stress, nativity, and risk for maternal maltreatment of young children. Am J Public Health. 2009;99(1):175-183

6. SurveyUSA. Disciplining a child 08/24/ 05. Available at: www.surveyusa.com/ 50StateDisciplineChild0805SortedbyTeacher. htm. Accessed July 3, 2009

7. Board of the Canadian Psychological Association. Policy statement on physical punishment of children and youth. Available at: www.docstoc.com/docs/5250464/Board-ofthe-Canadian-Psychological-AssociationPolicy-Statement-on. Accessed September 10, 2009

8. National Association of School Psychologists. Position statement on corporal punishment in schools. Available at: www.nasponline.org/ about_nasp/pospaper_corppunish.aspx. Accessed September 10, 2009

9. Durrant JE, Ensom R. Joint Statement on Physical Punishment of Children and Youth. Ottawa, Canada: Coalition on Physical Punishment of Children and Youth; 2004

10. Wolraich ML, Aceves J, Feldman HM, et al. Guidance for effective discipline. Pediatrics. 1998;101(4):723-728

11. Gershoff ET. Corporal punishment by parents and associated child behaviors and experiences: a meta-analytic and theoretical review. Psychol Bull. 2002;128(4): 539-579

12. Baumrind D, Larzelere RE, Cowan PA. Ordinary physical punishment: is it harmful? Comment on Gershoff (2002). Psychol Bull. 2002;128(4):580-589

13. Lansford JE, Criss MM, Dodge KA, Shaw DS, Pettit GS, Bates JE. Trajectories of physical discipline: early childhood antecedents and developmental outcomes. Child Dev. 2009; 80(5):1385-1402

14. Campbell SB, Pierce EW, Moore G, Marakovitz S, Newby K. Boys' externalizing problems at elementary school age: pathways from early behavior problems, maternal control, and family stress. Dev Psychopathol. 1996;8(4):701-719

15. Cohen $P$, Brook JS. The reciprocal influence of punishment and child behavior disorder. In: McCord J, ed. Coercion and Punishment in Long-Term Perspectives. New York, NY: Cambridge University Press; 1995:154-164

16. Grogan-Kaylor A. The effect of corporal punishment on antisocial behavior in children. Soc Work Res. 2004;28(3):153-162

17. Gunnoe ML, Mariner CL. Toward a developmental-contextual model of the effects of parental spanking on children's aggression. Arch Pediatr Adolesc Med. 1997; 151(8):768-775

18. Kandel DB, Wu P. Disentangling motherchild effects in the development of antisocial behavior. In: McCord J, ed. Coercion and Punishment in Long-Term Perspectives. New York, NY: Cambridge University Press; 1995:106-123

19. Singer JL, Singer DG, Rapaczynski WS. Family patterns and television viewing as predictors of children's beliefs and aggression. J Commun. 1984;34(2):73-89

20. Weiss B, Dodge KA, Bates JE, Pettit GS. Some consequences of early harsh discipline: child aggression and a maladaptive social information processing style. Child Dev. 1992;63(6):1321-1335

21. Grogan-Kaylor A. Corporal punishment and the growth trajectory of children's antisocial behavior. Child Maltreat. 2005;10(3): 283-292

22. Berlin LJ, Ispa JM, Fine MA, et al. Correlates and consequences of spanking and verbal punishment for low-income white, African American, and Mexican American toddlers. Child Dev. 2009;80(5):1403-1420

23. Reichman NE, Teitler J0, Garfinkel I, McLanahan SS. Fragile Families: sample and design. Child Youth Serv Rev. 2001;23(4/5): 303-326

24. Paolucci EO, Violato C. A meta-analysis of the published research on the affective, cognitive, and behavioral effects of corporal punishment. J Psychol. 2004;138(3):197-221

25. Achenbach TM, Rescorla LA. Manual for the ASEBA Preschool Forms and Profiles. Burlington, VT: University of Vermont, Research Center for Children, Youth, and Families; 2000
26. Lee SJ, Perron BE, Taylor CA, Guterman NB. Paternal psychosocial characteristics and corporal punishment of their 3-year old children. J Interpers Violence. In press

27. Brennan PA, Hall J, Bor W, Najman JM, Williams G. Integrating biological and social processes in relation to early-onset persistent aggression in boys and girls. Dev Psychol. 2003;39(2):309-323

28. Koblinsky SA, Kuvalanka KA, Randolph SM. Social skills and behavior problems of urban, African American preschoolers: role of parenting practices, family conflict, and maternal depression. Am J Orthopsychiatry. 2006;76(4):554-563

29. McFarlane JM, Groff JY, O’Brien JA, Watson K. Behaviors of children who are exposed and not exposed to intimate partner violence: an analysis of 330 black, white, and Hispanic children. Pediatrics. 2003; 112(3). Available at: www.pediatrics.org/ coilcontent/full/112/3/e202

30. Meadows S0, McLanahan SS, Brooks-Gunn J. Parental depression and anxiety and early childhood behavior problems across family types. J Marriage Fam. 2007;69(5): 1162-1177

31. Owens EB, Shaw DS. Predicting growth curves of externalizing behavior across the preschool years. J Abnorm Child Psychol. 2003;31(6):575-590

32. DeMulder EK, Denham S, Schmidt M, Mitchell J. Q-sort assessment of attachment security during the preschool years: links from home to school. Dev Psychol. 2000; 36(2): 274-282

33. Straus MA, Hamby SL, Finkelhor D, Moore DW, Runyan D. Identification of child maltreatment with the Parent-Child Conflict Tactics Scales: development and psychometric data for a national sample of American parents. Child Abuse Negl. 1998;22(4): 249-270

34. Straus MA, Hamby S, Boney-McCoy S, Sugarman D. The Revised Conflict Tactics Scale (CTS2): development and preliminary psychometric data. J Fam Issues. 1996;17(3): 283-316

35. Weiss RL, Margolin G. Assessment of marital conflict and accord. In: Ciminero AR, Calhoun KD, Adams HE, eds. Handbook of Behavioral Assessment. New York, NY: Wiley; 1977:555-602

36. Lloyd SA. Physical aggression, distress, and everyday marital interactions. In: Cahn DD, Lloyd SA, eds. Family Violence From a Communication Perspective. Thousand Oaks, CA: Sage; 1996:177-198

37. Abidin RR. Parenting Stress Index. 3rd ed. 
Odessa, FL: Psychological Assessment Resources; 1995

38. American Psychiatric Association. Diagnostic and Statistical Manual of Mental Disorders. 4th ed. Washington, DC: American Psychiatric Association; 1994

39. Kessler RC, Andrews G, Mroczek D, Ustun B, Wittchen HU. The World Health Organization Composite International Diagnostic Interview Short-Form (CIDI-SF). Int J Methods Psychiatr Res. 1998;7(4):171-185

40. Fragile Families Study Group. Fragile Families: scales documentation and question sources for three-year questionnaires: revised 4/26/06. Available at: www.fragilefamilies.princeton.edu/ documentation/core/scales/ff_3yr_scales.pdf. Accessed July 3, 2009

41. Becker WC, Peterson DR, Luria Z, Shoemaker DJ, Hellmer LA. Relations of factors derived from parent-interview ratings to behavior problems of five-year-olds. Child Dev. 1962; 33(2):509-535

42. Deater-Deckard K, Dodge KA, Bates JE, Pettit GS. Physical discipline among African American and European American mothers: links to children's externalizing behaviors. Dev Psychol. 1996;32(6):1065-1072

43. Engfer A, Schneewind KA. Causes and consequences of harsh parental punishment: an empirical investigation in a representative sample of 570 German families. Child Abuse Negl. 1982;6(2):129-139

44. Eron LD. Parent-child interaction, television violence, and aggression of children. Am Psychol. 1982;37 (2):197-211
45. Kandel DB. Parenting styles, drug use, and children's adjustment in families of young adults. J Marriage Fam. 1990;52 (1):183-196

46. Levin H, Sears RR. Identification with parents as a determinant of doll play aggression. Child Dev. 1956;27 (2):135-153

47. Mahoney A, Donnelly WO, Lewis T, Maynard C. Mother and father self-reports of corporal punishment and severe physical aggression toward clinic-referred youth. J Clin Child Psychol. 2000;29 (2):266-281

48. McCabe KM, Clark R. Family protective factors among urban African American youth. J Clin Child Psychol. 1999;28(2):137-150

49. McLeod JD, Shanahan MJ. Poverty, parenting, and children's mental health. Am Sociol Rev. 1993;58(3):351-366

50. Sears RR. Relation of early socialization experiences to aggression in middle childhood. J Abnormal Soc Psychol. 1961;63(3): 466-492

51. Simons RL, Lin K-H, Gordon LC. Socialization in the family of origin and male dating violence: a prospective study. J Marriage Fam. 1998;60 (2):467-478

52. Tang CS-K. Corporal punishment and physical maltreatment against children: a community study on Chinese parents in Hong Kong. Child Abuse Negl. 2006;30(8): 893-907

53. Pagani LS, Tremblay RE, Nagin D, Zoccolillo M, Vitaro F, McDuff P. Risk factor models for adolescent verbal and physical aggression toward mothers. Int J Behav Dev. 2004; 28(6):528-537
54. Nelson DA, Hart CH, Chongming Y, Olsen JA, Shenghua J. Aversive parenting in China: associations with child physical and relational aggression. Child Dev. 2006;77 (3):554-572

55. Sim TN, Ong LP. Parent physical punishment and child aggression in a Singapore Chinese preschool sample. J Marriage Fam. 2005;67(1):85-99

56. Bandura A. Aggression: A Social Learning Analysis. Englewood Cliffs, NJ: Prentice-Hall; 1973

57. Beauchaine TP, Webster-Stratton C, Reid MJ. Mediators, moderators, and predictors of 1-year outcomes among children treated for early-onset conduct problems: a latent growth curve analysis. J Consult Clin Psychol. 2005;73(3):371-388

58. Sege RD, Perry C, Stigol L, et al. Short-term effectiveness of anticipatory guidance to reduce early childhood risks for subsequent violence. Arch Pediatr Adolesc Med. 1997; 151(4):392-397

59. Barkin SL, Finch SA, Ip EH, et al. Is officebased counseling about media use, timeouts, and firearm storage effective? Results from a cluster-randomized, controlled trial. Pediatrics. 2008;122(1). Available at: www.pediatrics.org/cgi/content/full/122/ $1 / \mathrm{e} 15$

60. Taylor CA, Hamvas L, DeJong W, Rice JC. Normative Beliefs, Expectations, and Use of Corporal Punishment: Findings From an RDD Community Survey. Philadelphia, PA: American Public Health Association; 2009 


\section{Mothers' Spanking of 3-Year-Old Children and Subsequent Risk of Children's}

Aggressive Behavior

Catherine A. Taylor, Jennifer A. Manganello, Shawna J. Lee and Janet C. Rice Pediatrics published online Apr 12, 2010;

DOI: $10.1542 /$ peds. $2009-2678$

Updated Information

\& Services

Permissions \& Licensing

Reprints including high-resolution figures, can be found at:

http://www.pediatrics.org

Information about reproducing this article in parts (figures, tables) or in its entirety can be found online at:

http://www.pediatrics.org/misc/Permissions.shtml

Information about ordering reprints can be found online:

http://www.pediatrics.org/misc/reprints.shtml

\section{American Academy of Pediatrics}

